JPdK Volume 1 No 1 Tahun 2019 Halaman 1-10 JURNAL PENDIDIKAN dan KONSELING

Research \& Learning in Primary Education

UNIVERSITAS

\title{
Peningkatan Keterampilan Menulis Puisi Dengan Menggunakan Model Active Learning Teknik Card Sort Kelas V SDTI Batu Belah
}

\author{
Rosdiana Sri Defi ${ }^{1}$, Putri Hana Pebriana ${ }^{2}$ Zulhendri $^{3}$ \\ Program Studi Pendidikan Guru Sekolah Dasar \\ Fakultas Ilmu Pendidikan \\ Universitas Pahlawan Tuanku Tambusai \\ Email:Rosdianasridelfi@gmail.com
}

\begin{abstract}
Abstrak
Penelitian ini bertujuan penelitian ini untuk meningkatan keterampilan menulis siswa kelas $\mathrm{V}$ SD TI 030Batu Belah.MetodePenelitian ini adalah Penelitian Tindakan Kelas (PTK).Setiap siklus terdiri dari dua pertemuan dan empat tahapan,yaitu perencanaan, pelaksanaan, observasi, refleksi.Subjek penelitian ini siswa kelas V yang berjumlah 20 orang, dengan jumlah siswa laki-laki 7 orang, dan siswa perempuan berjumlah 13 orang. Teknik pengumpulan data berupa dokumentasi, observasi, dan tes. Hasil penelitian ini menunjukkanbahwa hasil keterampilan menulis siswa pada pelajaran Bahasa Indonesia materi puisidi kelas V SD TI 030 Batu Belah pada siklus I tergolong cukup dengan rata-rata 70,05 . Selanjutnya dari 20 orang siswa hanya 12 orang yang tuntas dengan ketuntasan klasikal 60,00\%. Pada siklus II tergolong baik dengan rata-rata 81,05 dari 20 orang siswa terdapat 17 orang siswa yang tuntas dengan ketuntasan klasikal 85\%. Dengan demikian dapat disimpulkan model Active Learning teknik Card Sortdapat meningkatkan keterampilan menulis siswa pada pelajaran Bahasa Indonesia materi puisi pada siswa kelas V SDN TI 030 Batu Belah.
\end{abstract}

Kata Kunci: Keterampilan menulis, Model Active Learning teknik Card Sort, Puisi

\begin{abstract}
This study aims to improve the writing skills of fifth grade students of SD TI 030 Batu Belah. This research method is Classroom Action Research (CAR). Each cycle consists of two meetings and four stages, namely planning, implementation, observation, reflection. The subjects of this study were grade V students, amounting to 20 people, with the number of male students 7 people, and female students amounting to 13 people. Data collection techniques in the form of documentation, observation, and tests. The results of this study indicate that the results of students' writing skills in Indonesian language poetry material in class V SD TI 030 Batu Belah in the first cycle is quite sufficient with an average of 70.05. Furthermore, out of 20 students, only 12 completed with classical completeness of $60.00 \%$. In the second cycle classified as good with an average of 81.05 of 20 students there were 17 students who completed with $85 \%$ classical completeness. It can be concluded that the Active Learning model of Card Sort technique can improve students' writing skills in Indonesian language poetry material in fifth grade students of SDN TI 030 Batu Belah.
\end{abstract}

Keyword: Write Skills, Active Learning technique Card Sort, Poetry 


\section{PENDAHULUAN}

Pendidikan memiliki peranan penting dalam mencerdaskan kehidupan bangsa.Melalui pendidikan inilah suatu bangsa dapat menjadi bangsa yang tangguh, mandiri, berkarakter dan berdaya saing. Selain itu, pendidikan juga dipandang sebagai salah satu aspek yang memiliki peranan pokok dalam mempersiapkan sekaligus membentuk generasi muda dimasa yang akan dating.Keberhasilan pembangunan suatu bangsa ditentukan oleh kualitas pendidikan warga bangsa tersebut. Karena dengan pendidikan yang baik manusia dapat mencapai kesejahteraan hidup, mengembangkan potensi dirinya, mewujudkan kehidupan lebih baik dan berpartisipasi secara aktif dalam pembangunan.

Pembelajaran Bahasa Indonesia di Sekolah Dasar memiliki tujuan untuk mencapai kompetensi yang harus dikuasai oleh siswa. Tujuan mata pelajaran Bahasa Indonesia menurut tim penyusun KTSP (2007:54) untuk satuan Pendidikan dasar SD/ MI adalah:

1. Berkomunikasi secara efektif dan efisien sesuai dengan etika yang berlaku, baik secara lisan maupun tertulis.

2. Menghargai dan bangga menggunakan bahasa Indonesia sebagai bahasa persatuan dan bahasa Negara

3. Memahami bahasa Indonesia dan menggunakannya dengan tepat dan kreatif untuk berbagai tujuan

4. Menggunakan bahasa Indonesia untuk meningkatkan kemampuan intelektual, serta kematangan emosional dan sosial

5. Menikmati dan memanfaatkan karya sastra untuk memperluas wawasan, memperhalus budi pekerti, serta meningkatkan pengetahuan dan kemampuan berbahasa

6. Menghargai dan membanggakan sastra Indonesia sebagai khasanah budaya dan intelektual manusia Indonesia

Berdasarkan uraian di atas dapat disimpulkan bahwa tujuan pembelajaran Bahasa Indonesia di sekolah dasar adalah untuk meningkatkan kemampuan siswa berkomunikasi secara lisan dan tertulis, dapat meningkatkan kemampuan intelektual yang dimilikinya serta menghargai Bahasa Indonesia sebagai bahasa Nasional Indonesia serta untuk meningkatkan karakter siswa.

Salah satu aspek keterampilan berbahasa yang harus diperhatikan yaitu keterampilan menulis. Keterampilan tersebut penting mengingat dalam kehidupan sehari-hari siswa tidak akan lepas dari kegiatan menulis. Menurut $\mathrm{H}$. G. Tarigan(2008: 2) keterampilan berbahasa menulis merupakan keterampilan yang dipergunakan untuk berkomunikasi secara tidak langsung dengan lawan bicaranya.Selain itu, keterampilan berbahasa menulis juga termasuk kegiatanyang produktif dan ekspresif.

Pembelajaran Bahasa Indonesia di sekolahhendaknya mampu membantu siswa meningkatkan keterampilan berbahasamenulis anak dengan baik secara maksimal. Pembelajaran keterampilan menulis di sekolah dasar idealnya tidak hanyabertujuan untuk mengajarkan keterampilan menulis dalam bentuk karangan maupun laporan, akan tetapi juga untuk mengajarkan keterampilan menulis karyasastra yaitu puisi.

Berdasarkan Observasi lapangan yang dilakukan peneliti di SDTI 030 Batu Belah pada hari rabu tanggal 20 Februari 2019 di kelas V bahwa dalam 
pembelajaran bahasa Indonesia guru masih menggunakan model yang konvensional, guru kurang dapat menarik perhatian minat siswa untuk belajar sehingga siswa merasa enggan untuk terlibat secara aktif, selain itu guru kurang menerapkan media - media pembelajaran yang menarik minat siswa untuk belajar dan kurangnya perhatian siswa terhadap penjelasan guru.berdasarkan data hasil belajar siswa terungkap bahwa masih banyak siswa yang tergolong rendah.dari 32 orang siswa hanya 6 siswa $(18,75 \%)$ yang mencapai KKM, dan 26siswa $(81,25 \%)$ belum mencapai nilai KKM.

Berbagai permasalahan yang ditemukan dalam pembelajaran keterampilan menulis puisi di kelas $\mathrm{V}$ SDTI Batu Belah Maka, untuk mengatasi berbagai permasalahan tersebut akan diterapkan suatu model pembelajaran baru yang kreatif, inovatif, dan dapat melibatkan siswa secara aktif dalam proses pembelajaran yaitu model ActiveLearning teknik Card Sort. $\begin{array}{lr}\text { Berdasarkan latar belakang } \\ \text { tersebut maka } & \text { peneliti } \\ \text { merekomendasikan penelitian } & \text { dengan }\end{array}$ merekomendasikan penelitian dengan
judul "Peningkatan keterampilan menulis puisi dengan menggunakan model Active Learning teknik Card Sort kelas V SDTI Batu Belah"

Berdasarkan latar belakang yang telah diuraikan diatas, maka terdapat beberapa masalah dalam pembelajaran sebagai berikut:

1. Model pembelajaran yang digunakan guru dalam pembelajaran keterampilan menulis puisi masih konvensional

2. Kemampuan menulis puisi siswa kelas V SDTI masih rendah.

3. Minimnya penguasaan kosakata, siswa kesulitan mengungkapkan ide maupun pikirannya dalam bentuk menulis puisi.

Berdasarkan identifikasi masalah di atas dapat dirumuskan masalah dalam penelitian ini, yaitu Bagaimanakah peningkatan keterampilan menulis puisi dengan menggunakan model Active Learning Teknik Card Sort siswa kelas V SDTI 030 Desa Batu Belah?

\section{METODOLOGI PENELITIAN}

Metode yang digunakan dalam penelitian ini adalah penelitian tindakan kelas (PTK) atauClassroom Action Research, yaitu penelitian yang dimaksud untuk memberikan informasi bagaimana tindakan yang tepat untuk meningkatkan mutu pembelajaran di kelas yang diteliti. (Arikunto, 2016: 2). Menurut Kokom Komala Sari(2012: 51) mengatakan bahwa PTK sebagai penelitian yang mengombinasikan prosedur penelitian dengan tindakan substantif, suatu tindakan yang dilakukan dalam disiplin inkuiri, atau suatu usaha seseorang untuk memahami apa yang sedang terjadi, sambil terlibat dalam sebuah prosedur perbaikan dan perubahan.

Subjek Penelitian ini adalah siswa kelas V SDTI Batu belah yang berjumlah 20 orang siswa. Adapun yang terlihat dalam penelitian ini yaitu peneliti bertindak sebagai guru praktis dikelas, guru kelas V SDTI Batu belah sebagai observer 1, dan teman sejawat sebagai observer II.tiap siklus dilaksanakan 2 kali pertemuan. Pelaksanaan masing - masing tiap siklus mengikuti tahap - tahap perencanaan, tindakan, observasidan refleksi.

Berhasil tidaknya penelitian dilakukan dapat diketahui dari data yang diperoleh. Terkait dengan itu, untuk memperoleh data dalam menjawab masalah penelitian dapat dilakukan 
dengan menggunakan instrumen penelitian yaitu sebuah alat bantu yang dipilih peneliti dalam kegiatan pengumpulan data, agar kegiatan tersebut berjalan dengan sistematis. Arikunto (dalam Sarjana, 2010:43).Data penelitian yang digunakan dalam penelitian tindakan kelas ini berupa observasi dan tes sebagai metode utama untuk memperoleh data.

Instrumen penelitian adalah alat atau fasilitas yang digunakan peneliti dalam mengumpulkan data agar pekerjaannya lebih mudah dan hasilnya lebih baik, dalam arti lebih cermat, lengkap dan sistematis sehingga lebih mudah diolah.Agar penelitian ini dapat dilaksanakan dengan baik maka perlu dipersiapkan instrument penelitian. Adapun instrumen penelitian yang perlu dipersiapkan sebagai berikut

1. Lembar observasi berfungsi untuk menilai perencanaan pembelajaran yang akan dinilai oleh observer pada setiap pembelajaran siklus I dan siklus II.

2. Teknik evaluasi digunakan untuk mengumpulkan data tentang keterampilan menulis. Tes evaluasi ini menggunakan tes formatif berupa Lembar Tugas Siswa (LTS) yang diberikan kepada siswa untuk menulis keterampilan puisi yang akan dilaksanakan pada saat proses pembelajaran siklus I dan II.

3. Dokumentasi berupa video siswa saat proses pembelajaran

Teknik pengumpulan data merupakan langkah yang paling strategis dalam penelitian karena tujuan utama dari penelitian adalah untuk mendapatkan data. Adapun teknik pengumpulan data yang akan diambil sebagai berikut:

1.Tes
Tes digunakan untuk mengumpulkan data tentang keterampilan menulis. Tes evaluasi ini menggunakan tes formatif berupa Lembar Tugas Siswa (LTS) yang diberikan kepada siswa untuk menulis keterampilan puisi yang akan dilaksanakan pada saat proses pembelajaran siklus I dan II.

2. Non tes

Lembar observasi berfungsi untuk menilai perencanaan pembelajaran yang akan dinilai oleh observer pada setiap pembelajaran siklus I dan siklus II.

Analisis data yang digunakan dalam penelitian ini adalah analisis kuantitatif dan analisis kualitatif.Analisis kuantitatif digunakan untuk menganalisis nilai rata-rata dan persentase skor hasil keterampilan menulis karangan narasi siswa. Sedangkan analisis kualitatif digunakan untuk menganalisis lembar observasi kegiatan siswa dan guru saat proses pembelajaran. Berikut penjelasannya:

1. Analisis Kuantitatif

a. Ketuntasan Belajar Individu

Adapun pedoman rubrik yang digunakan dalam penelitian keterampilan menulis karangan narasi siswa SDN 015 Tandun.Peneliti membuat rubrik penilaian karangan narasi untuk menilai hasil karangan narasi siswa. Adapun aspek yang dinilai ada 3 yaitu :

1) Diksi

2) Tema.

3) Amanat.

Siswa dikatakan tuntas apabila nilainya mencapai KKM atau lebih tinggi dari KKM yaitu 75. Untuk menentukan 
ketuntasan yang dicapai siswa peneliti menggunakan rumus yang digunakan yaitu:

\begin{tabular}{|c|l|l|}
\hline No & Interval & Kategori \\
\hline 1 & $90-100 \%$ & Baik Sekali \\
\hline 2 & $80-89 \%$ & B a i k \\
\hline 3 & $70-79 \%$ & C u k u p \\
\hline 4 & $60-69 \%$ & K u r a n g \\
\hline 5 & $<59 \%$ & Sangat Kurang \\
\hline
\end{tabular}

KBSI

$$
=\frac{\text { Skor yang diperoleh siswa }}{\text { Skor Maksimum }} \times 100
$$

Keterangan :

KBSI = Ketuntasan Belajar Siswa

Secara Individu

b. Ketuntasan Klasikal

Jika ketuntasan

klasikal siswa telah mencapai

$80 \%$ dari seluruh siswa, maka

secara klasikal telah tercapai dengan baik. (Wardhani, 2007:25).

$$
K K=\frac{\text { Jumlah Siswa yang tuntas }}{\text { Jumlah Seluruh siswa }}
$$

Keterangan:

KK = Ketuntasan Klasikal Adapun kriteria

proses pembelajaran keterampilan menulis karangan narasi dapat dilihat pada tabel berikut:

\section{HASIL PENELITIAN DAN PEMBAHASAN}

Peneliti melakukan observasi sebelum melakukan tindakan, yaitu untuk mengetahui kemampuan siswa dalam menulis puisi. Data dari observasi dan wawancara awal yang dilakukan dengan guru kelas V SDTI 030 Batu Belah kecamatan Kampar kabupaten Kampar, peneliti menganalisis data keterampilan menulis puisi siswa pratindakan, dengan tujuan untuk mengetahui peningkatan hasil keterampilan menulis siswa pada pembelajaran Bahasa Indonesia pada materi Puisi.

Berdasarkan data nilaiketerampilan menulis siswa sebelum tindakan dari 32 orang siswa hanya $6(18,75 \%)$ siswa yang mencapai KKM, dan $26(81,25 \%)$ siswa belum mencapai nilai KKM.

\section{A. Deskripsi Hasil Tindakan Tiap Siklus}

Perbandingan keterampilan menulis puisi dengan menggunakan model Active Learning teknik Card Sort kelas V di SDTI 030 Batu Belah pada siklus I dan siklus II terdapat peningkatan pada keterampilan menulis puisi dengan menggunakan model Active Learning teknik Card Sort kelas V di SDTI 030 Batu Belah. Dilihat dari tabel 4.4 terdapatnya peningkatan pada keterampilan menulis puisi menggunakan model Active Learning teknik Card Sortkelas v sdti 030 batu belah.diketahui bahwa nilai rata-rata siswa pada siklus I meningkat menjadi $70,05 \%$ dengan kategori cukup (70\%-79\%), kemudian pada siklus II mengalami peningkatan menjadi $80,00 \%$ dengan kategori baik (80\%-89\%). Sedangkan presentase ketuntasan klasikal keterampilan menulis pusi bebas pada siklus I meningkat menjadi $60,00 \%$ dengan kategori kurang (60\%-69\%), kemudian pada siklus II meningkat menjadi $85,00 \%$ dengan kategori baik (80\%-89\%).untuk mengetahui secara jelas peningkatan stiap siklus dapat dilihat pada diagram dibawah ini : 


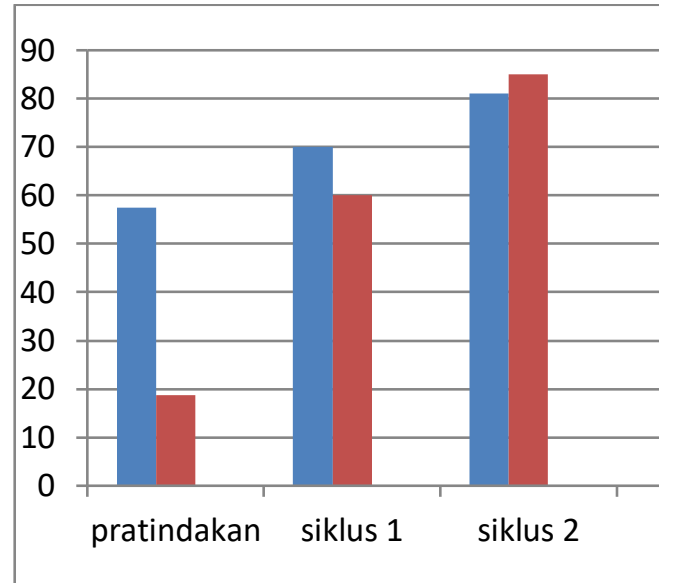

Gambar 4.1

(Grafik Perbandingan Nilai Siswa Pratindakan, Siklus I dan Siklus II)

Dilihat dari diagram diatas, dapat dilihat hasil keterampilan menulis puisi baik secara klasikal maupun secara nilai rata-rata yang diperoleh siswa mengalami peningkatan.

Berdasarkan dari hasil penelitian yang telah dilakukan , maka beberapa hal yang dibahas terkait penelitian ini adalah :

\section{Perencanaan Peningkatan \\ Keterampilan menulis puisi \\ Dengan Menggunakan Model Pembelajaran Active Learning teknik Card Sort}

Pada perencanaan pelaksanaan siklus I dan siklus II dalam pembelajaran Bahasa Indonesia pada materi puisi pada siswa kelas V SDN TI 030 Batu Belah, perencanaan pembelajaran perlu dibuat sebagaimana yang dikemukakan (Suyatno, 2009) setiap guru pada satuan pendidikan berkewajiban menyusun RPP secara lengkap agar pembelajaran berlangsung secara inspiratif, menyenangkan, menantang, memotivasi peserta didik untuk berpartisipasi aktif, serta memberikan kreativitas, dan kemandirian sesuai dengan bakat dan minat.

Sebelum melakukan tindakan, peneliti terlebih dahulu harus membuat perencanaan karena proses pembelajaran perlu direncanakan, seperti yang dikemukakan (Arikunto, 2015) seorang guru dapat melakukan perencanaan dalam membuat PTK seperti merancang skenario pembelajaran, dan menetapkan indikator pencapaian, serta menyusun instrumen penelitian. Adapun perencanaan yang disusun oleh peneliti dalam penelitian ini adalah, menyusun silabus, menyusun RPP berdasarkan tahapan pada model Active Learning teknik Card Sort yaitu,mempersiapkan lembar observasi aktivitas guru, mempersiapkan lembar observasi aktivitas siswa, meminta guru kelas yaitu ibu Rina Juliati,S.Pd untuk menjadi observer I mengamati aktivitas guru dan meminta kesediaan teman sejawat yaitu Anisa Ulfa untuk menjadi observer II mengamati aktivitas siswa, serta mempersiapkan lembar tugas siswa.

Adapun komponenkomponen penting yang ada dalam rencana pembelajaran meliputi: identitas sekolah, standar kompetensi (SK), kompetensi dasar (KD), Indikator, tujuan pembelajaran, materi pokok, penerapan langkah-langkah modelActive Learning teknik Card Sort, sumber pembelajaran, dan penilaian. Berdasarkan dari penilaian yang dilakukan oleh 
observer I terhadap perencanaan yang dilakukan oleh peneliti pada siklus I adalah persiapan yang dilakukan oleh guru praktisi seperti kesesuaian antara indikator dengan SK dan KD sudah sesuai, kemudian pemilihan materi ajar telah sesuai dengan tujuan pembelajaran, pemilihan materi ajar telah sesuai dengan karakteristik peserta didik, serta kesesuaian antara pemilihan materi ajar dengan alokasi waktu juga sudah sesuai.

Secara keseluruhan, penilaian dalam perencaan ini sudah lumayan baik meskipun masih perlu diperbaiki lagi. Sedangkan pada siklus II penilaian yang diberikan oleh observer I terhadap perencanaan yang telah dilakukan adalah kesesuaian antara indikator dengan SK dan KD nya sudah sesuai, kemudian pemilihan materi ajar telah sesuai dengan tujuan pembelajaran, pemilihan materi ajar telah sesuai dengan karakteristik peserta didik, serta kesesuaian antara pemilihan materi ajar dengan alokasi waktu juga sudah sesuai.

Skenario pembelajaran telah sesuai dengan metode yang digunakan yaitu model Active Learning teknik Card Sort. Berdasarkan penilaian tersebut dapat disimpulkan bahwa perencanaan yang dilakukan oleh peneliti pada siklus II ini sudah jauh lebih baik daripada siklus sebelumnya.

2. Proses Pembelajaran Bahasa Indonesia Pada Materi Puisi Dengan Menggunakan Model Active Learning teknik Card Sort

\begin{tabular}{cc}
\multicolumn{2}{c}{ Berdasarkan } \\
pelaksanaan pada siklus $\mathrm{I}$,
\end{tabular}

pembelajaran masih belum maksimal.Siswa diharapkan dapat bertanggung jawab ketika diberikan tugas.Ini dikarenakan kurangnya pengawasan guru terhadap siswa ketika siswa sedang mengerjakan tugas, sehingga siswa masih ada yang tidak bekerja dalam menyelesaikan tugasnya.Kemudian penyebab lainnya adalah siswa masih bersifat pasif ketika pembelajaran berlangsung, maksudnya siswa masih belum berani mengemukakan pendapatnya ketika guru memberikan pertanyaan seputar materi yang diajarkan.

Keterampilan menulis siswa masih rendah ketika menuangkan ide, dan juga ketika menulis puisi juga masih belum sesuai dengan aspek-aspek dalam penilaian keterampilan menulis.Dalam hal ini, guru perlu melakukan bimbingan yang lebih terhadap siswa, agar siswa merasa nyaman sehingga berani menyampaikan ide dan pendapatnya terkait pembelajaran.

Hal ini sesuai dengan yang dikemukakan oleh (Danim, 2011) yang menyatakan peserta didik memerlukan pembinaan, bimbingan dan pengembangan secara individual dan kelompok, serta mengharapkan perlakuan yang baik dan manusiawi dari gurunya.

Pada siklus II ini sudah berjalan lebih baik daripada siklus sebelumnya. Hal ini ditandai dengan siswa sudah lebih memperhatikan guru ketika guru menyampaikan materi pelajaran, siswa juga sudah lebih aktif dalam proses pembelajaran dan berani mengemukakan pendapatnya atau menjawab pertanyaan yang 
diberikan oleh gurunya. Hal ini sesuai dengan yang disampaikan oleh (Hamalik, 2013) yang menyatakan bahwa bukti bahwa seseorang telah belajar adalah terjadinya perubahan tingkah laku pada orang tersebut, misalnya dari tidak tahu menjadi tahu, dari tidak mengerti menjadi mengerti. Pada siklus II ini siswa juga sudah mampu dalam mengerjakan tugas pada pelajaran Bahasa Indonesia pada materi puisi sudah mengalami peningkatan. Berdasarkan hasil pelaksanaan pada siklus I hingga siklus II ini, keterampilan berbicara siswa pada pembelajaran Bahasa Indonesia materi puisi dengan menggunakan model Active Learning teknik Card Sort mengalami peningkatan pada siswa kelas V SDN TI 030 Batu Belah.

\section{Peningkatan Keterampilan menulis Siswa Dengan Menggunakan model Active Learning teknik Card Sort}

sebelum diterapkannya model Active Learning teknik Card Sort, diketahui bahwa hasil belajar siswa terhadap pelajaran Bahasa Indonesia pada materi puisi masih kurang, yaitu dengan rata-rata 57,40, sedangkan ketuntasan klasikalnya yaitu $18,75 \%$. Hal ini disebabkan karena selama ini guru masih menggunakan metode lama, dan pembelajaran hanya terfokus pada guru sedangkan siswa hanya mencatat pada buku catatan, sehingga siswa menjadi merasa bosan.Hal ini seperti yang diungkapkan oleh (Daryanto, 2009) salah satu faktor yang mempengaruhi hasil belajar siswa berasal dari luar atau eksternal, misalnya metode belajar dan mengajar. Jika guru tidak mampu menerapkan metode mengajar yang menarik, maka siswa akan cepat merasa bosan dan semangat belajarnya menjadi menurun.

Hasil keterampilan menulis siswa pada siklus I mengalami peningkatan dari sebelumnya yaitu dari 57,40 menjadi 70,05. Pada siklus ke II, rata-rata hasil belajar siswa adalah 81,05. Dari 20 orang, sebanyak 17 orang telah mencapai ketuntasan secara individual, sedangkan ketuntasan siswa secara klasikal telah mencapai $85 \%$ atau hanya 3 orang saja yang tidak tuntas. Secara klasikal, hasil belajar siswa telah mencapai kriteria yang telah ditetapkan.Berdasarkan ketuntasan klasikal di atas, dapat disimpulkan bahwa nama siswa yang tidak tuntas pada siklus II ini sama dengan nama siswa yang tidak tuntas pada siklus pertama, yaitu KF dengan nilai pada siklus I adalah 60, dan nilai pada siklus ke II adalah 60. Kemudian ada MAR dengan nilai pada siklus I adalah 60, ada RA dengan nilai pada siklus I adalah 60 dan pada siklus kedua adalah 50, dan siswa yang bernama TNR dengan nilai siklus adalah 55 .

Penyebab siswa tersebut tidak tuntas adalah karena pada saat pembelajaran berlangsung mereka asyik bermain dibangku mereka yang jaraknya berdekatan, kemudian kepercayaan diri siswa tersebut juga rendah, mereka tidak mau ketika diminta oleh guru untuk menyampaikan pendapat. 


\section{SIMPULAN}

Berdasarkan hasil analisis data perencanaan, proses dan hasil keterampilan menulis puisi bebas siswa dengan menggunakan model Active Learning teknik Card Sort pada siklus I dan siklus II telah mencapai sasaran yaituadanya peningkatan keterampilan menulis puisi siswa kelas V SDTI Batu Belah.Keterampilan menulis puisi siswa kelas V SDN 030 Batu Belah, nilai rata-rata siswa pada pratindakan adalah 57,40 dengan kategori Sangat kurang $(<55 \%)$ pada siklus I meningkat menjadi 70,05 dengan kategori cukup (70\%-79\%), kemudian pada siklus II mengalami peningkatan menjadi 81,05 dengan kategori baik (80\%-89\%). Sedangkan presentase ketuntasan klasikal keterampilan menulis pusi bebas pratindakan adalah $18.75 \%$ (11 siswa) dengan kategori kurang sekali $(<59 \%)$, pada siklus I meningkat menjadi 60,00\% (12 siswa) dengan kategori kurang (60\%-69\%), kemudian pada siklus II meningkat menjadi $85.00 \%$ (17 siswa) dengan kategori baik (80\%-89\%).

Berdasarkan hasil peneitian di atas, maka saran peneliti yang berhubungan dengan penelitian ini adalah sebagai berikut:

1. Untuk meningkatkan hasil keterampilan menulis puisi bebas siwa kelas V, disarankan guru SDTI 030 Batu Belah dapat model Active Learning teknik Card Sort .

2. Untuk meningkatkan kualitas pembelajaran, disarankan kepada guru SDTI 030 Batu Belah dapat model Active Learning teknik Card Sort.

3. Untuk meningkatkan kualitas sekolah, disarankan kepada sekolah untuk lebih mengawasi proses pembelajaran di kelas, agar kegiatan belajar mengajar yang dilaksanakan guru dapat dilaksanakan dengan baik.

\section{DAFTAR PUSTAKA}

Anisyah.(2015). Penggunaan Metode Pembelajaran Card Sort Untuk Meningkatkan Hasil Belajar Ips Pada Mata Pelajaran Ekonomi Siswa Kelas VIII Di Smp Negeri 1 Karangmalang Sragen

Arikunto, dkk (2015). Penelitian Tindakan Kelas.Jakarta:PT Bumi Aksara

Aveus, H. (2011). Yuk, Menulis Diary, Puisi, dan Cerita Fiksi.Yogyakarta:G-media

Danim, S. (2011).Perkembangan peserta didik. Bandung: Alfabeta.

Djago, T. (2001). Pendidikan Keterampilan Berbahasa. Jakarta:Universitas Terbuka

Daryanto, (2009).Panduan Proses Pembelajaran. Jakarta: AV Publisher.

Elitot (2012 ).Langkah Mudah Penelitian Tindakan Kelas sebagai Pengembangan Profesi Guru. Jakarta:Rajawali

Faizah,H. (2009). Bahasa Indonesia.Pekanbaru: Cendikia Insani

Ganie, T.N.(2015). Buku Induk Bahasa Indonesia.Yogyakarta : Araska Publisher.

Hamalik, (2013). Proses Belajar Mengajar. Jakarta: Bumi Aksara.

Hariyanto, dkk (2012) Active Learning.Bandung: Nusamedia

Haryadi, Z. (1996). Peningkatan Keterampilan Berbahasa Indonesia.Jakarta: Depdikbud.

Indah, A.P. (2016). Peningkatan Keterampilan Menulis Puisi Menggunakan Model Think Talk Write Berbantuan Media Gambar 
Kejadian Alam Pada Siswa Kelas Viii B Smp Negeri 4 Wates, Universitas Negeri Yogyakarta.

Ketut, S. (2016).Penerapan Strategi Pembelajaran Card Sort Untuk Meningkatkan Aktivitas Dan Hasil Belajar Ipa Kelas V SDN 3 Tukadmungga Kecamatan Buleleng Kabupaten Buleleng.

Kunandar.(2012). Langkah Mudah Penelitian Tindakan Kelas sebagai
Pengembangan ProfesiGuru.Jakarta : Rajawali.

Kundharu, S. (2012).Meningkatkan Keterampilan Berbahasa Indonesia.Bandung: Karya Putra Darwati.

Lewin.(2012). Langkah Mudah Penelitian Tindakan Kelas sebagai Pengembangan Profesi Guru.Jakarta : Rajawali. 